\title{
LUGAR DE MULHER É ONDE ELA QUISER: A ATUAÇÃO DAS DIRIGENTES DAS ASSOCIAÇÕES RURAIS EM CHUPINGUAIA E VILHENA, RONDÔNIA
}

\author{
Angra de Souza Santana ${ }^{1}$ \\ José Kennedy Lopes Silva² \\ Emerson Roberto de Araújo Pessoa ${ }^{3}$
}

\begin{abstract}
RESUMO
A pesquisa tem como objeto de análise a atuação das dirigentes de associações rurais, enquadradas como organizações convivenciais, localizadas nos municípios de Vilhena e Chupinguaia, no estado de Rondônia. Foi adotada uma metodologia qualitativa, com técnicas de coleta de dados por meio de entrevistas semiestruturadas e observação-participante. As entrevistas foram aplicadas a mulheres dirigentes das associações rurais, dirigentes do sexo masculino e a órgãos públicos que atuam em contato direto com essas organizações convivenciais. As análises dos dados indicam que falta compreensão por parte dos companheiros das entrevistadas, dos homens dirigentes de associações e dos representantes dos órgãos públicos sobre a importância da atuação feminina e sobre as dificuldades de atuação que as mulheres presidentas de associações rurais experienciam no interior de uma cultura machista, que compreende o trabalho feminino como "ajuda".
\end{abstract}

Palavras-Chave: Gênero; Mulheres; Associações rurais; Organizações convivenciais.

\footnotetext{
${ }^{1}$ Graduada em Administração pelo Departamento Acadêmico de Administração pela Universidade Federal de Rondônia (UNIR). Pesquisadora do Grupo de Pesquisa e Extensão sobre Gêneros, Discursos e Comunicação na Amazônia Ocidental - HIBISCUS.

2 Professor do Departamento Acadêmico em Administração da Universidade Federal de Rondônia (UNIR).

Pesquisador do Grupo de Pesquisa e Extensão sobre Gêneros, Discursos e Comunicação na Amazônia Ocidental HIBISCUS.

3 Professor do Departamento Acadêmico de Administração da Universidade Federal de Rondônia (UNIR). Doutor pelo Programa Inter-universitário OpenSoc: Sociologia, Conhecimento Para as Sociedades Abertas e Inclusivas (Universidade de Lisboa - UL, Universidade Nova de Lisboa - UNL, Universidade de Évora - UE e Universidade do Algarve - UAlg). Pesquisador do Grupo de Pesquisa e Extensão sobre Gêneros, Discursos e Comunicação na Amazônia Ocidental - HIBISCUS.
} 


\section{LUGAR DE MUJER ES DONDE ELLA QUISER: LA ACTUACIÓN DE LAS DIRIGENTES DE LAS ASOCIACIONES RURALES EN CHUPINGUAIA-RO Y VILHENA, RONDÔNIA, BRAZIL}

\section{RESUMEN}

La investigación tiene como objeto de análisis el desempeño de los líderes de las asociaciones rurales, enmarcadas como organizaciones de convivencias, ubicadas em los municipios de Vilhena y Chupinguaia, estado de Rondônia en Brasil. Se adoptó una metodologia cualitativa, con técnicas de recolección de datos por medio de entrevistas semiestructuradas y observaciónparticipante. Las entrevistas se aplicaron a mujeres líderes de asociaciones rurales, hombres líderes y organismos públicos que trabajan em contacto directo con estas organizaciones convivencias. Los análisis de los datos indican que existe una falta de comprensión por parte de los camaradas, líderes masculinos de las asociaciones y representantes de los organismos públicos sobre la importancia y las dificultades de acción que las presidentes de las asociaciones rurales experimentan dentro de una cultura machista que entiende el trabajo de las mujeres como "ayuda".

Palabras clave: Género; Las mujeres; Asociaciones rurales; Organizaciones Convivencias.

\section{A WOMAN'S PLACE IS WHEREVER SHE WANTS IT TO BE: THE ROLE OF RURAL ASSOCIATION LEADERS IN CHUPINGUAIA AND VILHENA, RONDÔNIA, BRAZIL}

\section{ABSTRACT}

The objective of this research is to analyze the performance of the leaders of rural associations, framed as community organizations, located in the municipalities of Vilhena and Chupinguaia, state of Rondônia, Brazil. A qualitative methodology was adopted, as well as semi-structured interviews and participant observation as data collection techniques. The interviews were applied to women leaders of rural associations, male leaders and public agencies that work in direct contact with these coexisting organizations. Data analyses indicate that there is a lack of understanding on behalf of the interviewees' partners, of male leaders of the associations and of representatives of public institutions about the importance of female presence and the difficulties that female presidents of rural associations experience within a macho culture that understands women's work as "help”.

Keywords: Gender; Women; Rural associations; Community organizations. 


\section{INTRODUÇÃo}

A participação feminina no mercado de trabalho, as diferenças salariais e o papel social da mulher têm demonstrado a importância da igualdade de gênero no ambiente laboral. Para Barbosa (2014), há um considerável aumento da participação feminina no mercado de trabalho tanto no Brasil quanto em outras partes no mundo, porém ainda existem diferenças entre as condições e situação de trabalho em relação aos homens. Não obstante, o desenvolvimento de pesquisas acadêmicas, ainda há um amplo campo de debates e investigações a serem desenvolvidas, principalmente em relação aos setores que possuem limitações geográficas e de acesso, como, por exemplo, o setor rural. Apesar de as mulheres estarem presentes nas atividades produtivas no campo, são inúmeras as limitações relacionadas às relações de gênero nesse setor.

Segundo dados do Instituto Brasileiro de Geografia e Estatística (IBGE) (2010), as mulheres representavam 47,38\% da população residente no campo. A região Norte representava $14,07 \%$ e a população rural feminina, 46,02\%; no Estado de Rondônia, residem 9,81\% das mulheres da região, correspondendo a 45,5\% da população rural do Estado, o que atesta a expressiva presença feminina no setor rural. No entanto, mesmo com essa participação preponderante no setor, a mulher não está inserida nesse espaço de maneira igualitária. Verifica-se, assim, a necessidade de problematizar de maneira progressista as questões relacionadas às discussões de gênero no campo.

Para Scott (1995), o conceito de "gênero" foi apropriado por diferentes correntes teóricas, o que teria conduzido a alguns equívocos. Para a autora, o termo deve ser compreendido como as diferenças constituídas histórica e culturalmente em relação aos sexos masculino e feminino. Butler (2010) afirma que o gênero não está relacionado apenas às diferenças biológicas entre homens e mulheres, mas também às práticas reguladoras que instituem uma repetição estilizada dos atos que são responsáveis por condicionar o gênero ao binarismo. Desse modo, a masculinidade e a feminilidade são entendidas como atos performativos que buscam inserir os agentes no interior de uma lógica social pautada pela dominação masculina e pela heteronormatividade compulsória. As autoras partem da discussão pós-estruturalista de gênero, a qual, segundo Souza (2016), equivale a 
pensamentos formados por aspectos históricos, sociais, culturais e políticos instáveis alicerçados nas relações de saber e poder.

Sob esse ponto de vista, é compreensível que a identidade da mulher não seja determinada por sua compleição biológica, mas antes por sua absorção social como indivíduo. Nesse sentido, a mulher pode desenvolver qualquer atividade que um homem também desenvolva e pode ocupar os lugares que quiser. A busca pela equidade de gênero, principalmente nas relações de trabalho, passa pela luta por oportunidades iguais.

Para Alves (2016), é nessa busca pela igualdade que se embatem os contextos históricos e culturais que impedem a simetria no mercado de trabalho pautado pela divisão sexual. A mulher, no campo, assim como em outras áreas, tem seu trabalho compreendido como mera "ajuda", sem o devido reconhecimento da sua contribuição e atuação nos trabalhos rurais (BRUMER, 2004). Quaresma (2015) afirma que, no campo, prevalece uma hierarquização entre o trabalho de homens e mulheres, o que as leva a serem reconhecidas apenas como colaboradoras do trabalho masculino. Essa perspectiva faz com que as atividades das mulheres não sejam reconhecidas no ambiente de trabalho em que estão inseridas.

Considerando que esse tema pode proporcionar importantes discussões sobre trabalho, gênero e emancipação feminina, este estudo procura dar resposta à seguinte questão de pesquisa: como a atuação das mulheres dirigentes de associações rurais são determinadas e impactadas pelas representações sociais sobre o papel feminino nos municípios de Chupinguaia e Vilhena, localizados no Estado de Rondônia?

A partir das discussões de Alves (2016) e Quaresma (2015), pressupõe-se que há modos de atuação das mulheres dirigentes de associações rurais, os quais se destacam no campo de pesquisa das relações de gêneros no ambiente rural. Nesse sentido, o objetivo deste artigo é identificar e compreender as possibilidades de participação, dificuldades e limitações na atuação das dirigentes de associações rurais. Paralelamente, busca-se analisar e relacionar esses obstáculos com as representações sociais sobre o papel feminino por meio das discussões e paradigmas propostos pelos Estudos de Gênero e os Feminismos sobre a estrutura social machista, excludente e inferiorizante da atuação das mulheres no espaço 
público e/ou em cargos de liderança. Para isso, utilizou-se a abordagem qualitativa como método de pesquisa. Os dados foram produzidos por meio de entrevistas semiestruturadas, aplicadas às mulheres e aos homens dirigentes de associações rurais dos municípios de Chupinguaia e de Vilhena e as suas respectivas Secretarias Municipais de Agricultura, assim como à Empresa de Assistência Técnica e Extensão Rural (EMATER). Nas análises dos dados, foi utilizada a técnica de análise de conteúdo.

Compreendida as discussões introdutórias deste artigo e as diferentes perspectivas teóricas sobre o conceito de gênero, no próximo tópico, problematizar-se-ão as relações das mulheres em ambientes de organizações convivenciais, considerando que as associações rurais pertencem a esse tipo de instituição. Em seguida, são apresentados os procedimentos metodológicos instrumentalizados neste estudo, posteriormente, analisar-se-ão as perspectivas das pessoas dirigentes mulheres e homens das associações rurais, bem como as dos dirigentes de órgãos públicos que participaram da pesquisa. Por fim, apresenta-se a conclusão das principais considerações sobre a atuação dos atores pesquisados, as perspectivas futuras e as limitações desta pesquisa.

\section{CONSIDERAÇÕES SOBRE GÊNERO}

As primeiras organizações feministas surgiram por meio da luta pelos direitos civis que antes eram assegurados apenas aos homens, esse debate foi liderado por mulheres liberais no início do século XX. O movimento sufragista é considerado protagonista nesses processos de lutas desse primeiro momento dos Movimentos Feministas (NARVAZ; KOLLER, 2006).

A partir dos anos de 1970, verificou-se uma revolução nos estudos relacionados a gênero influenciados por transformações importantes no estado brasileiro, como o processo de democratização, transformação geográfica e crises econômicas que resultaram em uma agenda de reformas (FARAH, 2001). Os Movimentos Feministas passaram por uma crise devido à incapacidade de sustentar a ideia de uma "mulher universal", uma vez que era impossível a caracterização dos diversos marcadores sociais capazes de revelarem todas as diferenças que estão incluídas no grupo de mulheres (HARAWAY, 2009). Assim, começou a se 
pensar o feminino e as suas relações com as questões sociais, culturais, de classe, de etnia e de gênero (BENOIT, 2000).

Scott (1995) afirma que, enquanto o sexo designa o biológico, o gênero seria a caracterização dos papéis sociais atribuídos ao sexo. As relações assimétricas de gênero naturalizaram os homens como dominantes e as mulheres como dominadas, sendo que essa dominação é construída socialmente por intermédio da naturalização das relações de poder. Pesquisas recentes como a de Alves (2016), Morgado e Tonelli (2016) e Conceição (2016) têm proporcionado avanços, discutindo e problematizando os papéis tipicamente atribuídos a homens e a mulheres.

No seguimento das discussões sobre os papéis relacionados aos corpos sexuados, Butler (2010) afirma que o gênero se deslinda da categorização do sexo biológico como masculino ou feminino; o gênero é um construto social, cultural e histórico. 0 corpo generificado não é construído apenas pelos seus atributos biológicos, mas incide sobre ele as relações de poder situadas no tempo e no espaço. Portanto, a constituição de homens e mulheres está relacionada aos processos de incorporação das relações de poder. Gênero é algo que se faz e desfaz a partir dos processos regulados por normas sociais. Desse modo, ninguém possui um gênero autêntico, pois se trata de uma identificação pautada na repetição estilizada de atos com a qual o sujeito de forma involuntária é forçado a se identificar (CARRIERI et al., 2016; BUTLER, 2010).

Os estudos sobre a temática proporcionaram a atual percepção da ligação de gênero ao cenário social e cultural. No trabalho, as relações de gênero têm-se mostrado determinantes para definir as oportunidades e os percursos dos indivíduos. De fato, apesar de todas essas discussões, o mercado de trabalho ainda reproduz estereótipos de gênero e diferenças de oportunidade para homens e mulheres. Galeazzi et al. (2003) demonstram que há relutância na aceitação de mulheres em cargos que exijam algum tipo de força física ou de tomadas de decisões. 0 mercado consequentemente atribui à mulher o papel de funções que possuem relação com o doméstico, como se coubesse ao feminino apenas as tarefas de arrumar, cuidar e organizar, e aos homens, as de administrar, prover e tomar decisões. Esses seriam os problemas de divisão do trabalho a partir de visões estereotipadas de gênero, que tendem a querer pré-determinar socialmente aonde as pessoas podem chegar. 
As divisões de gêneros presentes no mercado de trabalho não facilitam à mulher a ascensão a cargos e posições hierárquicas de gerenciamento. Muitas vezes, elas sofrem discriminação e enfrentam condições menos favoráveis de trabalho (GALEAZZI et al., 2003). Para Silva et al. (2016), as problematizações em relação a essas questões de equidade de gênero no trabalho devem reivindicar mudanças no ambiente laboral de forma a fazer valer a igualdade por oportunidades, independente do sexo da pessoa e das atribuições sociais ligadas ao sexo biológico. Essas mudanças, mesmo que se trate de um processo lento e árduo, são extremamente necessárias.

A atuação da mulher no trabalho rural também está diretamente ligada às questões de gênero. Nesse setor, por características históricas e culturais, as mudanças ocorrem de forma ainda mais lenta em comparação a outros ambientes de trabalho. Faria (2009) argumenta que, na Constituição Federal de 1988, foram estabelecidos alguns direitos básicos, como, a liberdade, a educação, a saúde e a segurança, garantidos às trabalhadoras rurais, resultado da mobilização e organização das mulheres.

Para o Instituto de Pesquisa Econômica Aplicada (IPEA) (2012) e para Kinoshita e Batilani (2016), o trabalho atribuído a mulher do campo ainda está ligado a atividades reprodutivas domésticas não remuneradas, que não têm grande valor econômico e não são socialmente reconhecidas. Nesse contexto, também se está longe da igualdade de gênero.

\section{AS MULHERES, IDENTIDADES E O AMBIENTE DAS ORGANIZAÇÕES CONVIVENCIAIS RURAIS}

A inserção das mulheres em novos ambientes de trabalho tem sido uma conquista gradual. Trata-se de um processo ainda em construção. No entanto, elas já participam e protagonizam as atividades dos mais variados setores. Para Cielo et al. (2014), as mulheres têm conquistado seus espaços, apesar de ainda enfrentarem diversos desafios para adquirirem seu reconhecimento no mercado laboral e nos cargos de gestão. Barbosa (2014) afirma que a participação das mulheres no campo rural saiu da estagnação na década de 1990 para um decréscimo dos anos 2000 até 2012. A inclusão feminina no espaço rural também se deu e se dá de maneira lenta. Apesar de sempre ter havido participação ativa, seu papel esteve - e ainda está - fortemente caracterizado somente como "ajuda" - um papel 
coadjuvante, portanto a hierarquização no campo esteve sempre relacionada a uma rígida divisão do trabalho entre homens e mulheres fazendo, assim, com que o papel da trabalhadora rural não fosse equiparado ao do homem nos espaços de produção (QUARESMA, 2015).

Em relação à divisão sexual do trabalho, para Faria (2009, p. 18),

\begin{abstract}
Os homens são designados prioritariamente à esfera produtiva enquanto que as mulheres à esfera reprodutiva, e ao mesmo tempo há a apreensão pelos homens das atividades de maior valor agregado. Essa formulação permite abordar a relação entre produção e reprodução, explica a simultaneidade das mulheres nos trabalhos produtivo e reprodutivo e sua exploração diferenciada no mundo produtivo e no trabalho assalariado.
\end{abstract}

As típicas divisões de tarefas no trabalho colocam a mulher sempre no papel de subordinada e evidenciam desigualdades de oportunidades. Além de serem atribuídos cargos de menor hierarquia ou complexidade às mulheres, é sabido que elas enfrentam uma dupla jornada de trabalho, pois são elas que geralmente fazem as tarefas domésticas, além de trabalharem fora de casa. De fato, especialmente no campo, elas se desdobram entre o trabalho remunerado e o não remunerado, enquanto os homens desempenham apenas o papel que lhes cabe nas atividades remuneradas (ALVES, 2016).

Como afirma Gomes (2010), essa divisão desigual e injusta do trabalho se apresenta de forma homogênea para as mulheres que, mesmo participando dos mais variados setores, inclusive aqueles considerados tipicamente masculinos, ainda enfrentam as mazelas do trabalho doméstico e reprodutivo. A dupla jornada de trabalho é um dos fatores que mais dificultam o acesso das mulheres a cargos de gerenciamento. Morgado (2012) afirma que essa conciliação resulta em uma sobrecarga na sua rotina e impacta a sua saúde física e mental. Muitas vezes, precisamente por isso, as mulheres acabam desistindo dos cargos de gestão, vendo-se incapazes de conciliar esses múltiplos papéis: mãe, dona de casa, trabalhadora, dirigente, entre outros. 
É necessário trazer o trabalho das mulheres ao protagonismo no ambiente rural, tirar as suas atividades da invisibilidade econômica, conforme relata Faria (2009), perante ao sistema de produção do campo que é ainda gerido numa perspectiva machista. A autora discorre que é necessário a aplicação da economia feminista, um movimento de pensamento econômico que baseia suas práticas nas críticas ao sistema econômico dominante, promovendo a reflexão e se atendo às mulheres como protagonistas econômicas.

Carrieri et al. (2016) notam que não existem muitos estudos que se detenham nas questões de gênero no campo rural. A maioria das referências encontradas são relatadas a partir da agricultura familiar, onde se concentra a maior parte das mulheres envolvidas com atividades rurais. A agricultura familiar tem grande participação na economia nacional. Segundo a Embrapa (2014), a participação da agricultura familiar no valor bruto da produção nacional é de 38\%. Siliprandi (2017) discorre sobre a participação da mulher nas discussões da agroecologia, importante prática relacionada à agricultura familiar. A maior participação da mulher nessa atividade econômica demonstra a importância feminina para o desenvolvimento econômico.

A agricultura familiar tem um papel estratégico no País, mas os investimentos e o fortalecimento dessa área ainda são iniciais (CARVALHO, 2015). As mulheres do campo ainda enfrentam dificuldades no acesso a políticas voltadas a investimentos e a outros programas de auxílio ao produtor rural. Trata-se de um fato em harmonia com as características socioculturais do setor rural, onde o papel da mulher, conforme discutido anteriormente, é visto como inferiorizado e relegado a trabalhos mais precários e com as menores remunerações (CAMPOS, 2011).

Serrano (2015) afirma que a participação ativa das mulheres nos setores econômicos possibilita a troca de experiências e de conhecimento. Trata-se, de resto, de um reconhecimento de direitos e de um exercício de liberdade. Nesse contexto, entende-se que a inserção das mulheres nas associações rurais gradualmente proporcionará o reconhecimento do seu trabalho e isso contribuirá para o crescimento e desenvolvimento desse setor.

Souza e Carrieri (2012) propõem a discussão de identidade pautada na concepção de um indivíduo integral. Entretanto, em diferentes contextos, o indivíduo se apresenta de 
acordo com diferentes racionalidades e apoiado nestas. Assim, o indivíduo buscaria o equilíbrio entre atingir os objetivos organizacionais funcionalistas com a realização das suas prioridades pessoais. Essa perspectiva sobre o conceito de identidade será importante para compreender os diferentes papéis femininos nas organizações rurais. Para além da identidade individual, é salutar compreender o conceito de identidade coletiva, ou seja, aquelas que são identidades reconhecidas culturalmente, empreendedoras e identificadas em campos dinâmicos. Os posicionamentos nos campos não são estáticos, porque se modificam de acordo com as práticas de negociação e com as relações de poder, por exemplo, como se caracterizam as associações rurais. Os conceitos de identidade coletiva são importantes também, porque o conceito de identidade e identificação individual não são suficientes para compreender toda a dinâmica organizacional principalmente de organizações convivenciais que contém características peculiares (SOUZA; CARRIERI, 2012).

Para Daher e Seifert Júnior (2017), o espaço criado para uma convivencialidade possibilita equidade e autonomia e ultrapassa o objetivo do mero acúmulo de capital, promovendo a interação entre indivíduos. Nesse sentido, Fraser (2009) afirma que as chamadas "organizações convivenciais", ligadas ao desenvolvimento de organizações sem fins lucrativos, possibilitam a aproximação de um estágio participativo igualitário nas representações de gênero. Em outras palavras, essas associações possibilitam um ambiente mais propício à igualdade de gênero e à convivência da diversidade. Desse modo, elas se diferenciam das organizações burocráticas, focadas em aspectos técnicos e interessadas no fluxo material dos processos (RODRIGUES, 2013).

Nas organizações convivenciais, a hierarquia não tende a ser estabelecida com tanta consideração aos estereótipos de gênero (DAHER; SEIFERT JUNIOR, 2017). Ser mulher ou homem, nesse contexto, tende a ser apenas uma característica e as atividades e as relações não dependem disso. Por esse fato, as mulheres encontram nesse tipo de organização uma maior aceitação, quando comparado a outros locais, ou seja, os papéis de gerenciamento e de decisões não são tão restritos (FRASER, 2009).

As associações rurais têm como objetivo promover o bem-estar social como um todo e pretendem ser um espaço de convívio e de partilha que possa atender às necessidades de todos os seus associados. Esse tipo de espaço pode ser caracterizado como organizações 
convivenciais. As organizações rurais têm como objetivo promover aos seus associados uma voz mais ativa na sociedade, em torno do bem comum, propiciando melhores condições de bem-estar social e de sustentabilidade ao desenvolvimento rural (SENAR, 2010). A consequente agência e autonomia oferece contribuições às pessoas que participam dessas associações, reunindo indivíduos com afinidades para atender a necessidades específicas, tomando decisões em conjunto no intuito de que o bem comum possa ser alcançado (AMES; BUTTERNBENDER, 2012).

Contudo, mesmo nessas organizações, com essas características mais afins à equidade de gênero, ainda há resistências à igualdade no tratamento de homens e mulheres. Compreende-se que as mulheres têm a possibilidade de encontrar menos barreiras para ocupar espaços de decisão nas organizações convivenciais se comparadas às burocráticas. No entanto, o espaço rural é historicamente machista e ainda relega a mulher a segundo plano. Este trabalho parte do reconhecimento de que muito ainda há para ser feito.

\section{PROCEDIMENTOS METODOLÓGICOS}

A concepção filosófica construtivista social orientou esta pesquisa. 0 construtivismo social parte da compreensão de que as pessoas desenvolvem hábitos e comportamentos a partir do meio em que vivem e trabalham. Sendo assim, o pesquisador coleta o máximo de visões possíveis da realidade levando em consideração seu ambiente histórico, cultural e suas relações com o entorno (CASTAÑON, 2004). Para Hosking (2011), o construtivismo relacional dá ênfase ontológico às relações dos sujeitos nas produções de processos sociais.

A linguagem e/ou discurso é um dos processos de diálogo importante para o construtivismo social, pois se trata de um importante processo de interação para o desenvolvimento de uma pesquisa. Nesse sentido, Hosking (2011) destaca a necessidade da linguagem para a eficácia da pesquisa construtivista social.

Por meio das interações entre pessoas entrevistadas e pesquisadoras, são criados significados e sentidos interpretados em todo o contexto da pesquisa. Nesse relacionamento, há construção de relações de poder, porém a ontologia das relações reconhecidas no construcionismo relacional pode permitir um ambiente saudável nas interações sociais, 
caracterizando-se como um trabalho com base nas epistemologias e metodologias feministas (NARVAZ; KOLLER, 2006). Por isso, ocorreu a preocupação em discutir criticamente as relações de gênero do ambiente rural em um processo de reflexões e transformações sociais e, ao mesmo tempo, o papel das pessoas entrevistadas na pesquisa e a interferência das pessoas pesquisadoras em todo o processo de construção do trabalho.

A questão de pesquisa surgiu da curiosidade dos pesquisadores de compreender as temáticas relacionadas ao gênero e trabalho, especificamente no ambiente rural. A partir dessa questão, procedeu-se a revisão da literatura e a contextualização do referencial teórico. Em seguida, empreendeu-se o mapeamento de quais seriam as organizações estudadas no trabalho. Dessa forma, foram selecionadas as organizações rurais de caráter convivencial que possuem mulheres como dirigentes. Posteriormente, identificaram-se os órgãos que trabalham com essas organizações no intuito de produzir mais dados sobre a realidade pesquisada.

Neste trabalho, a população pesquisada foi obtida por meio do contato com associações rurais fornecidas pelo Sindicato dos Trabalhadores e pelos Trabalhadoras Rurais de Vilhena e de Chupinguaia. Ao todo, 40 associações rurais foram listadas. Foram obtidos os nomes dos seus respectivos presidentes, homens ou mulheres. Assim, foram identificadas 12 associações com mulheres na liderança, sendo uma delas a própria dirigente do Sindicato que cedeu a lista das respectivas associações.

Por meio do contato com as presidentas, foi possível obter os órgãos que trabalham em conjunto com associações e sindicatos. Esses órgãos também passaram a integrar o conjunto de pessoas pesquisadas, são eles a Secretaria Municipal de Agricultura de Vilhena (SEMAGRI) e a EMATER-RO unidade de Vilhena. Entrevistou-se também uma amostra dos presidentes homens que atuam à frente das associações. Os investigadores inseriram na pesquisa os representantes de órgãos públicos e presidentes homens para que fosse possível ampliar as perspectivas de análises. Assim, a diversidade de atores possibilitou a triangulação dos dados, o que possibilitou uma maior compreensão do contexto pesquisado. As análises das narrativas das pessoas entrevistadas foram realizadas por meio da análise de conteúdo e serão apresentadas nas discussões dos resultados. 
Os instrumentos utilizados para a coleta de dados da pesquisa foram as entrevistas semiestruturadas e a observação não participante em uma das reuniões da central de associações de Vilhena. Essa reunião teve como pauta principal a eleição da nova diretoria. As entrevistas semiestruturadas são formadas por perguntas abertas e fechadas; tanto a pessoa entrevistada quanto a entrevistadora tem participação ativa na conversa. A pessoa pesquisadora assume o papel de direcionar a entrevista de forma que não se fuja do tema proposto. Essa prática possibilita informações mais precisas, pois fixa limites quanto ao volume de informações e possui um direcionamento mais definido, ao mesmo tempo em que abre a possibilidade de intervenções para alcançar os objetivos da pesquisa (GODOY, 2010).

Para as entrevistas, foram utilizados blocos, cadernos de anotações e gravadores, que proporcionaram às pessoas pesquisadoras uma melhor organização e memorização dos dados coletados no intuito de permitir uma análise mais complexa de informações. A pesquisa ocorreu previamente entre os meses de agosto e setembro de 2017. Para a coleta de dados com as presidentas das associações, as entrevistas foram baseadas nos seguintes questionamentos: 1) Como se deu a sua inserção nas atividades rurais? 2) No seu entender, quais são as perspectivas da participação das mulheres nas organizações rurais? 3) Para você, existem limitações ou dificuldades na participação das mulheres nas organizações rurais? 4) O que você acha importante a ser trabalhado para aumentar a participação das mulheres nas organizações rurais? 5) Como seus familiares lidam com sua atividade, uma vez que está em um cargo de comando? 6) Você diria que existe alguma discriminação por parte de algum órgão que trabalha em conjunto com a organização pelo fato de o cargo de liderança ser desempenhado por uma mulher?

As perguntas direcionadas aos órgãos públicos mencionados e aos demais presidentes homens das associações rurais foram: 1) Descreva como é a experiência de trabalhar com as mulheres dirigentes de organizações rurais. 2) Descreva como é a experiência de trabalhar com os homens dirigentes de organizações rurais. 3) Como o(a) senhor(a) caracteriza a participação das mulheres em cargos de gerenciamento de organizações rurais (positiva ou negativa)? 4) Para finalizar, em linhas gerais, como o(a) senhor(a) classificaria a atuação das mulheres no campo? Elas conseguem realizar as suas atividades como mães, esposas, como agricultora e como dirigentes de organizações rurais? 
Na pesquisa, não foram mencionados os nomes das mulheres líderes das associações, nem quais as organizações em que elas participam. No Quadro 1, são apresentadas informações que permitem compreender as características das pessoas participantes da pesquisa. Os nomes das entrevistadas não são reais; foram criados nomes fictícios para manter o sigilo das participantes, possibilitando, simultaneamente, uma melhor organização dos dados obtidos e o anonimato. Os nomes fictícios foram inspirados em mulheres que se destacam ou se destacaram nas discussões feministas.

\section{Quadro 1: Caracterização dos entrevistados}

\begin{tabular}{|c|c|c|}
\hline Nome & Representação & Características \\
\hline Marielle & Presidenta de Associação & $\begin{array}{l}\text { Nascida na zona rural, mudou-se para a zona urbana aos } 18 \text { anos. } \\
\text { Casou-se e, após o casamento, voltou a morar no campo; mãe de } \\
\text { uma filha. Desde } 2015 \text {, é presidenta do sindicato. }\end{array}$ \\
\hline Joanna & Presidenta de Associação & $\begin{array}{l}\text { Nascida na zona rural, ainda jovem se mudou para a cidade. Depois } \\
\text { de algumas décadas vivendo na zona urbana, retornou para o } \\
\text { campo, onde está há quase } 20 \text { anos. No momento da pesquisa, } \\
\text { tinha } 55 \text { anos, é casada, mãe de } 5 \text { filhos e avó de } 7 \text { netos. É } \\
\text { presidenta da associação e está no seu } 3^{\circ} \text { mandato. }\end{array}$ \\
\hline Monique & Presidenta de Associação & $\begin{array}{l}\text { Nascida na zona rural, onde sempre morou. Casada. Na data da } \\
\text { pesquisa, tinha } 52 \text { anos e presidia a associação desde } 2010 \text {. }\end{array}$ \\
\hline Sônia & Presidenta de Associação & $\begin{array}{l}\text { Há mais de uma década reside na zona rural. } 47 \text { anos, casada e mãe } \\
\text { de } 3 \text { filhos. }\end{array}$ \\
\hline Carmem & Presidenta de Associação & $\begin{array}{l}\text { Sempre residiu na zona rural. Veio para o Estado de Rondônia em } \\
2005 \text {, é casada e mãe de } 3 \text { filhos. Na época da pesquisa estava em } \\
\text { seu } 2^{\circ} \text { mandato como presidenta. }\end{array}$ \\
\hline Elza & Presidenta de Associação & $\begin{array}{l}\text { Associada desde } 2009 \text {, é casada e mãe de } 2 \text { filhos. No momento da } \\
\text { pesquisa, contava } 9 \text { anos de moradia na zona rural e estava em seu } \\
\text { segundo mandato de presidenta. }\end{array}$ \\
\hline Fernanda & $\begin{array}{l}\text { Vice-presidenta de } \\
\text { Associação }\end{array}$ & $\begin{array}{l}\text { Nascida na zona rural, mudou-se para a cidade, onde vive. É casada } \\
\text { e mãe de } 1 \text { filho. Nasceu no campo, mas atualmente mora na } \\
\text { cidade. }\end{array}$ \\
\hline Maria & Ex-presidenta de Associação & $\begin{array}{l}\text { Antes de residir na zona rural, morava na cidade onde exercia o } \\
\text { ofício de cabeleireira. Na época da pesquisa, já residia no campo há } \\
15 \text { anos e estava com } 51 \text { anos de idade. É casada e mãe de } 2 \text { filhos. }\end{array}$ \\
\hline
\end{tabular}

Fonte: Elaborado pelas pessoas pesquisadoras.

Em relação aos representantes dos órgãos públicos e aos homens entrevistados, foram criados códigos que apresentam essas informações, possibilitando, simultaneamente, uma melhor organização dos dados obtidos e o anonimato dos participantes. Para identificar os homens entrevistados, foram utilizados os códigos de "H1" até "H4". Por sua vez, os órgãos 
públicos foram identificados com os códigos “OP1" e "OP2". Essa formatação de identificação dos participantes teve como intuito uma maior organização dos dados da pesquisa e destacar principalmente as falas das mulheres associadas.

Como técnica de análise dos dados foi utilizada a Análise de Conteúdo. Dellagnelo e Silva (2005) afirmam o quanto é promissor e instigante a utilização da Análise de Conteúdo nas pesquisas em Administração, principalmente na abordagem qualitativa. É uma metodologia que utiliza como dados os discursos coletados por meio de entrevistas, documentos e observação (SILVA; FOSSÁ, 2015).

As análises do material empírico foram apoiadas em Oliveira et al. (2016) e Silva e Fossá (2015) com base em Bardin (1977; 2011) ao usar as fases da Análise de Conteúdo temática e ou categóricas, que são as seguintes: 1) pré-análise, 2) exploração e 3) tratamento e interpretação. Silva e Fossá (2015) reforçam a necessidade de as pessoas pesquisadoras em estudos organizacionais atentarem no uso devido da Análise de Conteúdo em seus trabalhos, assim as autoras orientam também a necessidade de se explicar as categorias utilizadas em cada fase de análise.

A partir do contexto apresentado por Oliveira et al. (2016) e Silva e Fossá (2015) foi realizada uma pré-análise dos dados e informações levantadas nas entrevistas com as mulheres e homens líderes das associações, assim como com os representantes dos órgãos públicos. Posteriormente, os dados dessa pré-análise foram lidos e analisados, o que possibilitou o tratamento e a interpretação dos dados que serão problematizados nas análises do trabalho.

A interpretação e análise dos dados produzidos durante os momentos de entrevistas com as mulheres e homens dirigentes de associações rurais e os representantes da SEMAGRI e da EMATER seguiram as orientações de Flick (2009). Assim, a triangulação foi realizada por meio do material empírico com o referencial teórico e as observações obtidas durante o trabalho de campo. Para facilitar a triangulação dos dados, foi criada uma planilha no programa Excel®. Assim, foi possível observar e relacionar as respostas das pessoas entrevistadas, obtendo uma melhor interpretação dos resultados. 
Por meio das análises, buscou-se refletir sobre os possíveis desafios, as limitações, os aprendizados e as conquistas que essas mulheres enfrentam/enfrentaram em suas trajetórias como dirigentes de associações rurais. A maior parte das pessoas entrevistadas apresentam certas características que, de certo modo, dificultaram a pesquisa. Por residirem na zona rural, foi difícil, contatá-las por telefone. Além disso, a lista cedida pelo Sindicato estava desatualizada, o que dificultou o contato com algumas dirigentes. Esses pontos podem ser considerados como um fator limitador na obtenção de uma amostra de pesquisa mais abrangente. Nem todas as presidentas foram entrevistadas devido à ausência de meios de contato. Já aquelas cujo contato foi obtido aceitaram prontamente participar do estudo.

Nesta pesquisa, houve a participação de uma ex-presidenta que fez parte do trabalho de campo e foi atuante no cenário pesquisado. As entrevistas foram feitas por telefone e também presencialmente. Ao todo, foram 14 pessoas entrevistadas, sendo oito mulheres presidentas e quatro homens presidentes das associações e dois representantes de órgãos públicos relacionados à agricultura.

\section{ANÁLISE E DISCUSSÃO DOS RESULTADOS}

O objetivo deste artigo é analisar a atuação das mulheres dirigentes em associações rurais localizadas no interior do Estado de Rondônia, local em que a agricultura familiar tem papel importante para a economia, principalmente nos municípios cuja principal base econômica é a agricultura, que é o caso de Vilhena e Chupinguaia.

Algumas características centrais dos agricultores familiares desses municípios é o longo tempo de atividade no campo, algumas das pessoas entrevistadas sempre trabalharam no campo em Rondônia e/ou em outros estados, principalmente no sul do País. A presença de agricultores oriundos do sul do País está relacionada ao processo de migração de Rondônia que foi majoritariamente de pessoas que vieram dos Estados de Santa Catarina, Paraná e Rio Grande do Sul.

A partir dos relatos das pessoas entrevistadas, pode-se afirmar que, no Estado de Rondônia, há inúmeras disputas políticas pelas distribuições das terras e conflitos agrários entre grandes e pequenos agricultores, o que torna as atividades das lideranças rurais árduas 
e complexas. Esse contexto de pesquisa ajudou os pesquisadores a compreenderem as narrativas e práticas discursivas das agricultoras, agricultores e representantes dos órgãos públicos entrevistados.

No intuito de compreender a realidade das pessoas agricultoras de Rondônia, instrumentalizaram-se as orientações de Silva e Fossá (2015) sobre a análise de conteúdo de acordo com as seguintes etapas: 1) pré-análise, 2) exploração e 3) tratamento e interpretação. Por intermédio dessas etapas, foi possível definir as seguintes categorias analíticas descritas no Quadro 2 e obtidas por meio das entrevistas com as mulheres gestoras de associações rurais; no Quadro 3, serão apresentadas as categorias analíticas das entrevistas com os dirigentes homens e, no Quadro 4, discorrer-se-á sobre as categorias analíticas dos representantes dos órgãos públicos.

Quadro 2: Categorias de análises das gestoras de associações rurais

\begin{tabular}{|c|c|c|c|}
\hline Categorias inici & & $\begin{array}{c}\text { Conceitos mediadores } \\
\text { (categorias intermediárias) }\end{array}$ & Categoria final \\
\hline $\begin{array}{l}\text { Campo } \\
\text { Cidade } \\
\text { Família produtora } \\
\text { Companheiro } \\
\text { Zona } \\
\text { Infância } \\
\text { Memória afetiva }\end{array}$ & $\begin{array}{l}\text { rural } \\
\text { Rural }\end{array}$ & $\begin{array}{l}\text { Moradia no campo, } \\
\text { conhecimento dos processos das } \\
\text { associações e inserção nas } \\
\text { atividades rurais }\end{array}$ & \\
\hline $\begin{array}{l}\text { Tomada de decisão } \\
\text { Paridade } \\
\text { Presença } \\
\text { Poucas oportunidades } \\
\text { Dificuldades }\end{array}$ & & $\begin{array}{l}\text { Perspectivas da participação das } \\
\text { mulheres nas organizações } \\
\text { rurais }\end{array}$ & \\
\hline $\begin{array}{l}\text { Sofrimento } \\
\text { Diminuição das } \\
\text { capacidades } \\
\text { Existência } \\
\text { Compreensão } \\
\text { Família/Lar } \\
\text { Locomoção } \\
\text { Espanto }\end{array}$ & suas & $\begin{array}{l}\text { Limitações da participação das } \\
\text { mulheres nas organizações } \\
\text { rurais se consolidam na falta de } \\
\text { confiança e compreensão da } \\
\text { família, investimento financeiro } \\
\text { e preconceitos. }\end{array}$ & $\begin{array}{l}\text { A inserção das dirigentes nas } \\
\text { atividades rurais e os desafios } \\
\text { enfrentados }\end{array}$ \\
\hline $\begin{array}{l}\text { Cursos de } \\
\text { Eventos } \\
\text { Marcha das Margaridas } \\
\text { Dinheiro } \\
\text { Comunicação } \\
\text { Chamar mais mulheres } \\
\text { Grito da Terra }\end{array}$ & itação & $\begin{array}{l}\text { Aumento da participação das } \\
\text { mulheres nas organizações } \\
\text { rurais com intuito de criação de } \\
\text { políticas públicas para a geração } \\
\text { de trabalho e renda. }\end{array}$ & \\
\hline $\begin{array}{l}\text { Família } \\
\text { Assentamento }\end{array}$ & & \begin{tabular}{lllr} 
Divisão & \multicolumn{2}{c}{ Familiar } \\
Familiares lidam com a sua
\end{tabular} & \\
\hline
\end{tabular}


Angra Santana, José Silva e Emerson Pessoa

Lugar de mulher é onde ela quiser: a atuação das dirigentes das associações rurais em

\begin{tabular}{|l|l|}
$\begin{array}{l}\text { Apoio } \\
\text { Não apoiam } \\
\text { Violência } \\
\text { Machismo }\end{array}$ & $\begin{array}{l}\text { atividade na presidência da } \\
\text { associação rural }\end{array}$ \\
\hline Existe & \\
Bem & Discriminação por parte dos \\
Não existe & representantes dos órgãos \\
púbcriminação no lar &
\end{tabular}

Preconceito

Dados: Elaborado pelas pessoas pesquisadoras.

Quadro 3: Categorias de análises dos gestores homens de associações rurais

\begin{tabular}{|c|c|c|}
\hline Categorias iniciais & $\begin{array}{c}\text { Conceitos mediadores } \\
\text { (categorias intermediárias) }\end{array}$ & Categoria final \\
\hline $\begin{array}{l}\text { Normal } \\
\text { Acordo } \\
\text { Tranquilidade } \\
\text { Positiva }\end{array}$ & $\begin{array}{lrr}\text { Relações de trabalho } & \text { com } \\
\text { mulheres dirigentes } & \text { de } \\
\text { associações rurais } & \end{array}$ & \multirow{3}{*}{$\begin{array}{l}\text { A visão masculina das atividades das } \\
\text { dirigentes de associações rurais }\end{array}$} \\
\hline $\begin{array}{l}\text { Difícil } \\
\text { Desacordos } \\
\text { Relapsos }\end{array}$ & $\begin{array}{l}\text { Relações de trabalho } \\
\text { homens com } \\
\text { associações rurais }\end{array}$ & \\
\hline $\begin{array}{l}\text { Multitarefas } \\
\text { Superação } \\
\text { Positiva }\end{array}$ & Atuação das mulheres no campo & \\
\hline
\end{tabular}

Fonte: Elaborado pelas pessoas pesquisadoras.

Quadro 4: Categorias de análises dos representantes dos órgãos públicos

\begin{tabular}{|c|c|c|}
\hline Categorias iniciais & $\begin{array}{c}\text { Conceitos mediadores } \\
\text { (categorias intermediárias) }\end{array}$ & Categoria final \\
\hline $\begin{array}{l}\text { Tímida } \\
\text { Sensível } \\
\text { Gênero } \\
\text { Masculino } \\
\end{array}$ & $\begin{array}{l}\text { Experiência em trabalhar com as } \\
\text { mulheres dirigentes de } \\
\text { organizações rurais }\end{array}$ & \multirow{4}{*}{$\begin{array}{l}\text { A visão dos representantes dos } \\
\text { órgãos públicos }\end{array}$} \\
\hline $\begin{array}{l}\text { Racionais } \\
\text { Objetivos }\end{array}$ & $\begin{array}{l}\text { Experiências em trabalhar com } \\
\text { os homens dirigentes de } \\
\text { organizações rurais }\end{array}$ & \\
\hline $\begin{array}{l}\text { Positiva } \\
\text { Efetiva } \\
\text { Políticas Públicas } \\
\text { Direitos }\end{array}$ & \begin{tabular}{lll}
\multicolumn{2}{l}{ Participação das mulheres } & em \\
cargos de gestão & em \\
organizações rurais &
\end{tabular} & \\
\hline $\begin{array}{l}\text { Jornadas duplas } \\
\text { Falta de comprometimento } \\
\text { familiar } \\
\text { Políticas Públicas }\end{array}$ & Atuação das mulheres no campo & \\
\hline
\end{tabular}

Fonte: Elaborado pelas pessoas pesquisadoras. 
Para melhor sistematização e organização dos dados produzidos durante as entrevistas e observação, serão apresentadas as análises e os resultados da investigação em uma estrutura narrativa a partir das categorias finais da análise de conteúdo. Primeiramente, será destacada como foi a inserção das mulheres nas atividades rurais e os desafios enfrentados por elas. Posteriormente, será discutida a visão dos presidentes das associações rurais sobre as atividades dessas dirigentes, por conseguinte, analisar-se-ão as visões dos representantes dos órgãos públicos que se relacionam com as dirigentes e as associações rurais. Por fim, serão sintetizadas algumas similaridades e divergências entre os posicionamentos das mulheres e homens dirigentes e dos representantes dos órgãos públicos.

\section{A inserção das dirigentes nas atividades rurais e os desafios enfrentados}

A maioria das mulheres entrevistadas sempre esteve em contato direto ou indiretamente com o campo, o que se adequa aos números apresentados pelo IPEA (2012). Algumas nasceram no campo e lá permanecem, e outras, em menor número, migraram da cidade para o campo. Sobre essa realidade, a entrevistada Marielle afirmou:

Nasci na área rural. Meus pais moram no campo, com 18 anos fui para a cidade [no estado do Paraná $]^{4}$. No entanto, tive frustrações, não era aquilo que imaginava ser. Os jovens do campo têm a ilusão que na cidade vai ser melhor, mas não foi. Dividia apartamento com uma amiga e o salário se resumia em pagar aluguel, alimentação e roupas. Permaneci 8 anos na cidade e foi quando me casei e voltei para a zona rural. Atualmente, estou há 8 anos em Rondônia. Em 2011, fui convidada para trabalhar no sindicato como secretária geral e em 2015 fui eleita presidente (Trecho da entrevista de Marielle, 2017).

Em relação à atuação como dirigentes, a maioria delas começou nas associações no cargo de secretária e, depois, por conhecerem todos os processos, foram eleitas presidentas, como na narrativa de Marielle. A entrevistada Sônia também passou por experiência semelhante: "Na associação, eu era secretária. Quando o atual presidente precisou se ausentar eu conhecia os processos da associação, fiquei com o cargo de presidente por um tempo, até que fui eleita oficialmente".

\footnotetext{
${ }^{4}$ Em todas as transcrições, procurou-se preservar os traços da oralidade presentes nos discursos das pessoas entrevistadas. Reproduz-se, assim, o que foi dito de um modo mais fidedigno.
} 
Esses relatos podem ser o mote para uma discussão sobre a divisão do trabalho, como relatado por Gomes (2010). 0 contexto histórico e cultural da sociedade ocidental naturalizou que às mulheres cabiam as tarefas domésticas e aos homens, o poder decisório conforme apontado por IPEA (2012) e Kinoshita e Batilani (2016). Sendo assim, mesmo que as entrevistadas hoje estejam em um cargo gerencial, elas tiveram de passar por um processo de convencimento de que elas eram capacitadas para a função, etapa esta que é dispensada aos homens.

O cargo de presidente de uma associação rural por si só já exige características específicas. Trata-se de um cargo eletivo não remunerado, que demanda tempo, compromisso e confronto político. Por isso, atualmente não existe muita concorrência para a ocupação desses cargos. A participação feminina na gestão dessas associações é ainda mais escassa, não apenas devido às especificidades apontadas, mas, sobretudo, por se tratar de um meio que, historicamente, caracteriza-se como masculino. Como relata Quaresma (2015) e conforme já adiantado, a caracterização histórica do papel da mulher em determinadas profissões fez com que as atividades desempenhadas pelas trabalhadoras do campo fossem consideradas coadjuvantes. Disso resulta que as mulheres ocupem apenas cargos como secretárias e/ou tesoureiras.

Durante a condução desta pesquisa, foi possível perceber que o número de mulheres em posição de liderança nas associações rurais tem crescido, apesar de ainda ser minoria. Para além dos já mencionados, vários outros fatores influenciam a baixa participação das mulheres, por exemplo, elas se declaram acuadas em um ambiente majoritariamente masculino. Falam também da falta de apoio familiar e de informação. Pode-se perceber a falta de suporte por meio do relato de Elza: "é dividido tem os que me apoiam e os que não. Igual meu marido não apoia, não concorda e nem me acompanha, é meio machista”. Esses fatores podem ser relacionados às violências e à invisibidade que as mulheres sofreram ao longo da história, à incorporação de características socialmente impostas pela própria família e ao ambiente social em que vivem.

A fala da entrevistada Maria indicia um aspecto importante que deve ser analisado. Ela menciona que essa crescente participação, mencionada anteriormente, não está tanto relacionada à aceitação das mulheres em espaços tradicionalmente machistas, mas, antes, 
prende-se ao fato de que os homens não têm mostrado interesse nos cargos de gestão para os quais as mulheres se propõem.

Eu acho que as mulheres têm participado mais porque é um trabalho que parece que os homens não estão assim querendo ocupar. Porque é um cargo que não é remunerado. Aí ocupa bastante tempo da gente e por isso eles estão se afastando um pouco (Trecho da entrevista de Maria, 2017).

A fala de Maria pode ser reiterada pelas observações do trabalho de campo. Durante uma reunião na central de associações de Vilhena, na qual a pauta principal da reunião era a eleição da nova diretoria, em um primeiro momento, o cargo foi colocado à disposição de quem quisesse se candidatar entre as pessoas membras das associações. Contudo, acabou não havendo muitas pessoas candidatas e a eleição se deu por indicação dos presentes na reunião. Por fim, a nova diretoria ficou composta por $80 \%$ de mulheres nos cargos principais de presidenta e vice-presidenta. Apesar dessas mulheres que assumiram a chefia possuírem extenso conhecimento da realidade sob o seu comando, é de se pensar que, se houvesse mais interesse masculino pelo cargo, a atuação feminina ficaria mais comprometida.

As dificuldades enfrentadas pelas mulheres não ficam por aí. Para Elza, as dirigentes "se sentem recuadas, não se sentem à vontade, [sentem] medo, medo de tomar a frente, dar cara a bater, enfrentar dificuldades". A fala da entrevistada indica que as mulheres têm a percepção de que assumir um compromisso maior nas associações rurais é algo mais dificultoso para elas do que para os homens. Portanto, não há equidade. As representações machistas sobre o gênero feminino colocam em dúvida a capacidade das mulheres de desempenhar determinadas atividades. À mulher é exigida infalibilidade em grau maior do que ao homem, o que parece indicar que o fracasso feminino é algo subentendido ou até esperado.

Nesse sentido, Elza afirma: "Para o homem já existe uma confiança. Agora a mulher não, ela tem que conquistar para que depois venha a confiança". As dificuldades do cargo são para ambos - homens e mulheres, como citado anteriormente. No entanto, para as mulheres, além das limitações inerentes ao cargo, são acrescidas outras: a pressão de trabalhar sem falhas e o pressuposto de que são incapazes de desempenhar determinada atividade. Todas 
essas discussões sobre as dificuldades encontradas pelas mulheres são apresentadas também por Carvalho (2015).

É muito importante reverter essa realidade da não participação feminina e das limitações acrescidas a esse público. Cursos, palestras e trocas de conhecimento poderiam ser um dos instrumentos para isso. É o que Marielle afirma: "cursos de capacitação faria abrir novos horizontes para elas [as dirigentes], intercâmbios entre as mulheres de outras associações, eventos como a Marcha das Margaridas $^{5}$ e o Grito da Terra ${ }^{6}$, isso chamaria a atenção das mulheres a participarem mais". A possibilidade de participar desses eventos representa uma oportunidade de conscientização e permitiria a união de forças, a partir do reconhecimento de que nenhuma mulher está sozinha na luta. Como afirma Serrano (2015), a troca de experiências também possibilita agência e autonomia no trabalho e na própria vida. Nessa mesma direção, Joanna afirma:

Olha eu tinha comentado até na reunião agora desse mês. A maioria das mulheres hoje em dia é independente, quer ter seu dinheiro e a renda na área rural é mais difícil do que na cidade. Por exemplo, a família que mora na cidade, todo mundo tem seu emprego. No sítio, às vezes a renda é só o leite e aquela renda tem que dividir para todo mundo. Eu vejo hoje [que] a melhoria seria muitos cursos de aprendizagem e abertura de vendas de produtos, no caso, porque a gente mora aqui em um distrito bem pequeno. Por exemplo, se todo mundo for vender a mesma coisa não vai ter mercado (Trecho da entrevista de Joanna, 2017)

A conquista financeira, o reconhecimento pelo trabalho desenvolvido e a possibilidade de se capacitar em algo são benefícios que os cursos e as palestras trariam para essas mulheres. Consequentemente, isso aumentaria a participação feminina na gestão das associações, o que possibilitaria a tão desejada independência financeira que foi discutida por Campos (2011) e pode ser percebida no relato de Joanna:

\footnotetext{
${ }^{5}$ Mobilização nacional organizada pelo Movimento Sindical de Trabalhadores e Trabalhadoras Rurais (MSTTR), de movimentos feministas e de mulheres que integram ações para organização e interação de mulheres de todo país para as reflexões sobre as condições da vida das mulheres no campo e nas florestas. ${ }^{6}$ Ação organizada pela Confederação Nacional dos Trabalhadores Rurais (CONTAG), Federações dos Trabalhadores na Agricultura (FETAGS), MSTTR e pelos Sindicatos dos Trabalhadores e Trabalhadoras Rurais (STTRS) com intuito de mobilizar os agricultores e agricultoras rurais e reivindicar políticas públicas para o campo e para a floresta.
} 
O que eu mais queria tentei projeto na Conab, esse projeto de alimentação das escolas o PA. Esse é um tipo de recurso que deveria ser muito valorizado porque a maioria desses projetos são das mulheres das associações, então aí o recurso que vem, 3.500 reais é muito pouco eu acho para o ano todo. Toda mulher gosta de andar bem arrumada, toda a mulher gosta de ter seu dinheiro, se aumentasse esse valor, esse capital para cada família, para a cada pessoa durante o ano, esse fim seria um bom motivo para as pessoas, as mulheres permanecerem na propriedade sem precisar com briga de arrumar empregos em prefeituras e sair das suas propriedades (Trecho da entrevista de Joanna, 2017).

Todas as dirigentes são casadas e possuem filhos, o que caracteriza a dupla ou tripla jornada de trabalho. Algumas delas contam com a ajuda de familiares, principalmente, mães, irmãs e alguns companheiros para conciliar as atividades exercidas nas associações rurais.

As mulheres dirigentes também se manifestaram a respeito da dificuldade de conciliar sua jornada de trabalho. Por ser uma tarefa que exige tempo e determinação, o apoio da família é de grande importância. Algumas mulheres afirmaram ter esse apoio; outras disseram que enfrentam problemas de aceitação em casa. É o caso de Carmem, que relata não ter muito apoio da família. A justificativa encontrada por ela é a seguinte: "por ser um cargo que exige muito e que sai muito de casa por causas dos compromissos reuniões entre outros compromissos. Por esse motivo, às vezes ninguém quer o cargo de presidência”. Marielle mencionou a sua relação com os filhos. Ela alega sofrer bastante por não poder ficar muito tempo com a filha, que ainda é bebê, por conta das inúmeras viagens que realiza. Apesar de Marielle se sentir apoiada pela família, ela afirma que:

Meu esposo no começo era apático, acho que por nós termos vindo de realidades diferentes. Eu sempre morei no campo, estava ligada a essa parte social em ações da igreja, já ele morava na cidade, não tinha muito conhecimento nessa área, com o tempo ele foi conhecendo meu trabalho e hoje ele dá muito apoio e até me acompanha às vezes. Agora sofro com minha filha de um ano, perco fases do crescimento dela por conta do meu trabalho. Logo quando eu casei, tentei engravidar e não consegui, já tinha desistido da ideia. Foi quando assumi a presidência, meses depois descobri que estava grávida. Sofro por causa das viagens, são muitas, mas sei que ela está bem cuidada pelo meu esposo e avós (Trecho da entrevista de Marielle, 2017). 
As discussões sobre as múltiplas tarefas desempenhadas por mulheres levantam questões sobre as escolhas que as mulheres precisam fazer ao longo de suas carreiras de trabalho: ter dedicação exclusivamente à casa, ao marido e aos filhos, ou se sacrificar quando optam por tentar conciliar duas realidades. Essa realidade leva muitas mulheres a abandonarem suas carreiras por conta do cuidado exclusivo com a família ou por se sentirem culpadas por optarem por trabalhar (MORGADO, 2012). Nesse contexto, é possível questionar o quanto uma participação masculina mais ativa nas tarefas domésticas e no cuidar dos filhos não seria benéfica para essas mulheres.

Outro aspecto mencionado pelas entrevistadas diz respeito à percepção que as mulheres têm em relação aos preconceitos ou a qualquer tipo de rejeição que sofrem durante o exercício de suas funções em cargos com poder de decisão. Quase todas afirmaram que nunca sofreram ou que não sofrem qualquer tipo de preconceito, conforme a narrativa de Monique:

Não sofro preconceito. Pelo contrário, sempre fui bem recebida [...] por todos eles [membros do sindicato], inclusive o atual [presidente da SEMAGRI]. Ele incentiva a maior participação das mulheres nas associações. Até porque, pra ele, nós mulheres temos mais clareza nas informações quando são passadas. As secretárias são mais objetivas e claras (Trecho da entrevista de Monique, 2017).

Essa afirmação também é feita pela entrevistada Fernanda, que relata que não existe preconceito e que existe equidade entre os gêneros. Tal discurso entra em contradição com outros aspectos vivenciados pelas entrevistadas e relatados nas entrevistas - por exemplo, a própria jornada dupla seria um forte indicativo da inexistência de igualdade.

De fato, em outros momentos da pesquisa, foi observado nas falas das entrevistadas um teor que evidencia algum tipo de tratamento diferenciado às lideranças femininas. Por exemplo, a entrevistada Marielle menciona que, em determinadas situações, as pessoas reagem com espanto quando se refere ao seu cargo. 0 espanto é fruto do quão inabitual ainda é ver uma mulher ocupando cargos de liderança. Permanece ainda um olhar hostil lançado à mulher que é líder, como se o esperado fosse que ela permanecesse em cargos de menor destaque. Trata-se de algo construído culturalmente. Para Gomes (2010), as pessoas esperam que as mulheres ocupem lugares de menor influência, enquanto os homens ocupam espaços 
de tomada de decisões. No contexto das associações rurais, o espanto ainda persiste, indicando que o que se espera das mulheres são os cargos de secretárias e cuidadoras.

\section{A visão masculina das atividades das dirigentes de associações rurais}

Em relação aos homens presidentes de associações rurais que se propuseram a participar da pesquisa, as respostas foram bastante lacônicas: muitas vezes, apenas um "sim" ou um "não", impossibilitando uma compreensão mais profunda do que pensam sobre o assunto em questão. Para os entrevistados, a experiência em trabalhar com mulheres dirigentes é "boa". As mulheres são descritas pelos homens como sendo "mais calmas" e "passivas". O entrevistado H2 afirma: "Trabalhar com mulher é melhor, mais fácil de mexer". O entrevistado H4 acrescenta: "normal, elas sentam e entram em um acordo". É interessante analisar o motivo pelo qual os homens afirmam ter uma visão positiva do trabalho com as mulheres. As características mencionadas pelos entrevistados se relacionam a uma posição servil: "sentam", "entram em acordo", são "calmas" e "passivas". Esses entrevistados reconhecem que a combatividade é tradicionalmente reservada ao homem; a mulher é vista como aquela que se submete, que concorda e que apazigua.

Os presidentes pesquisados também afirmam que trabalhar com homens é negativo. Para H2: "Os homens é mais difícil eles torce para um lado para outro. Você dá uma ideia, eles acham que outra ideia, com as mulheres você fala a ideia elas já entende. Elas trabalham melhor que os homens". Na narrativa de H2, não é possível perceber realmente se as mulheres agradam tanto em função de características que lhes são atribuídas de maneira intrínseca, ou por assumirem uma posição subalterna. As falas dos homens tacitamente reconhecem um papel dominante e de controle da situação. Gomes (2010) afirma que dos homens se espera uma reação mais agressiva, competitiva, enquanto às mulheres cabe ser cuidadosa, emotiva, passiva. Trata-se de uma caracterização construída socialmente, mostrando às mulheres limites aonde seus comportamentos podem chegar.

Em relação à caracterização da participação nas atividades de dirigentes mulheres, os entrevistados avaliam essa participação como positiva. O entrevistado H1 afirma: "assim como em todas as áreas e setores, nas associações não é diferente, elas têm um papel fundamental sim". Nessa fala, o entrevistado reconhece o papel feminino não só nas 
atividades sindicais rurais, mas também em todas as áreas do trabalho em geral. Os homens reconhecem que as mulheres desempenham um papel importante como conciliadoras nas atividades e tomadas de decisão. Quando questionados a respeito da mulher conseguir desempenhar um papel positivo como dirigentes de associações por conta das suas outras atividades, como esposas e mães, H1 afirma: "elas conseguem, as mulheres se desdobram em dez. No entanto, fica bem puxado, não apenas nas questões de associações, mas também em outros cargos de um modo geral. Elas assumem vários papéis, acaba gerando uma carga muito alta. Conseguem, porém com uma sobrecarga". Sobre esse assunto, H4, por sua vez, afirma: "sim, tranquilo, conseguem sim". H1 reconhece a sabida sobrecarga que pesa sobre a mulher, mas não as acham incapazes para a gestão e a liderança. Já H4 não consegue problematizar a dupla jornada feminina.

Nas falas de $\mathrm{H} 1$ e H4 é percebido o quanto o machismo ainda é presente no contexto rural, eles não compreendem que os trabalhos das mulheres presidentas das associações rurais são ainda mais complexos devido aos diversos papéis sociais atribuídos a elas. Por fim, as falas dos homens dirigentes de associações rurais demonstram que a atuação de mulheres dirigentes necessita ainda percorrer um longo caminho de debates para que os homens possam compreender o quanto é importante o ajuste dos trabalhos dessas mulheres para o crescimento e desenvolvimento do campo, do respeito às mulheres e, consequentemente, da diminuição do machismo. Ainda sobre as falas dos homens entrevistados, é possível compreender as discussões de Barbosa (2014) sobre as diferenças de condições de trabalhos entre homens e mulheres relacionadas à presença de filhos, à renda domiciliar per capita e ao nível educacional da mulher. Elas se deparam com barreiras na hora de exercer seus trabalhos fora de casa, o que faz com que sejam um número menor no mercado de trabalho e no processo de tomadas de decisões à frente das associações rurais e de outras funções relacionados ao trabalho no espaço rural.

\section{A visão dos representantes dos órgãos públicos}

Foram entrevistados representantes de dois órgãos públicos, os quais trabalham diretamente com as associações rurais de Chupinguaia e Vilhena. $\mathrm{Na}$ pesquisa, o representante do órgão OP1 é do gênero masculino e o órgão OP2 é representado por uma mulher. Para OP1, o trabalho com as mulheres dirigentes de associações rurais é positivo. Ele 
emprega, para se referir a elas, adjetivos como "detalhistas" e "maleáveis". OP2 também pensa de modo semelhante, mas frisa que a participação feminina é ainda "[...] tímida, por haver poucas mulheres, ainda permanece a maioria dos presidentes de associações do gênero masculino". Para OP2, a experiência de trabalhar com as dirigentes é também boa, pois elas "são mais dinâmicas, sensíveis e atuantes, conduzem de uma forma diferente". Já em relação ao trabalho com os homens, OP1 afirma: "é complicado, não sabem se expressar às vezes, falam o que pensam". Para OP2, esse contato com o público masculino é positivo: "os homens são racionais e objetivos".

Sobre a participação das mulheres como presidentas de associações rurais, para OP1, trata-se de algo positivo. "As mulheres sabem conversar, são mais dedicadas", afirma o representante. OP2 partilha dessa opinião, afirmando que "a participação das mulheres consolidam as políticas públicas que garantem mais direitos, o que às vezes é perdido e não se concretiza pelo fato das mulheres não participarem tanto". Entre essas políticas, OP2 cita o Programa de Aquisição de Alimentos (PAA) e enfatiza que esses programas e outros auxílios ajudam no empoderamento da mulher tanto no trabalho, quanto em relação a ter o próprio dinheiro visto que a questão econômica é o que torna as mulheres do campo mais vulneráveis financeiramente.

Quanto à conciliação das atividades das associações com o trabalho doméstico e com o papel de esposa e mãe, para OP1 "isso é fichinha para elas, elas conseguem conciliar muito bem todas essas atividades". Por sua vez, OP2 afirma:

Elas têm sim [a capacidade de conciliar jornadas duplas], desde que a mulher saiu para buscar trabalho ela tem essa capacidade. No entanto, isso ocasiona a dupla, tripla ou até quádrupla jornada de trabalho. Um reflexo negativo seria a família por causa dos filhos, por não dispor de tanto tempo para eles. Mas deve ter um equilíbrio para que a base, que é a família não seja comprometida, e o esposo deve ajudar também (Trecho da entrevista com OP2, 2017).

A fala de OP2 pode ser lida como um indicativo de que passa por algo semelhante, por também ser mulher, talvez por isso Sônia afirma que: "Não existe, o preconceito está mais na casa do que fora, eu nunca fui discriminada pelas secretarias por ser mulher. Sempre trataram iguais". 
Essas afirmações remetem novamente à discussão de Morgado (2012) sobre a sobrecarga a que a mulher muitas vezes é submetida ao tentar conciliar a tarefa do trabalho com as tarefas domésticas, com os filhos e com o companheiro. Fica evidente que, mais uma vez, os respondentes homens não problematizam essa realidade. Para eles, aguentar a sobrecarga é fácil, conciliar é "tranquilo".

Identificam-se, nesse contexto, necessidades de mudanças sobre as discussões feministas que se refiram ao padrão econômico e de gênero discutido por Faria (2009), pois são no contexto dessas discussões que o patriarcado se consolida ao invisibilizar o trabalho feminino devido às atividades domésticas não serem consideradas como laborais.

\section{Síntese das análises sobre a visão das dirigentes, dos dirigentes e dos órgãos públicos.}

Para as mulheres investigadas, a atuação feminina vem crescendo, mesmo que discretamente. Segundo elas, são vários os fatores que levam a essa não participação: dificuldades no cargo, falta de apoio familiar e o próprio desinteresse das mulheres de participarem das atividades das associações. Esses são pontos que indicam que o machismo ainda é muito forte no ambiente rural e que as discussões de gênero precisam perceber as necessidades das mulheres do campo. Para as presidentas, o cargo exige bastante, mas também é compensador por agregar aprendizados e experiências positivas em suas vidas.

Durante as entrevistas, algumas mulheres acrescentaram informações além do proposto nas perguntas, o que enriqueceu a coleta de análise dos dados, por exemplo, a entrevistada Marielle explicitou os desafios enfrentados pelos sindicatos de se relacionarem entre si, principalmente pela falta de escrituração das terras dos produtores rurais. Os receios dos agricultores estão relacionados ao medo de aumentar os seus investimentos e perderem os seus recursos financeiros, já que as terras não estão totalmente legalizadas. No relato de Marielle, não é considerado ainda a crítica discutida por Farah (2001) sobre a necessidade de políticas públicas referentes à questão agrária e ao reconhecimento de direitos relativos às mulheres da zona rural. Em algumas narrativas das presidentas, constatou-se a negligência dos políticos representantes do Estado de Rondônia no congresso nacional, na perspectiva dessas interlocutoras, os senadores e deputados direcionam seus esforços para atender aos grandes produtores rurais preterindo os agricultores familiares. 
Além das dificuldades já exemplificadas na discussão deste trabalho, deve ser retratado também que a participação das mulheres nas associações propicia a elas a possibilidade de certo protagonismo na comunidade, porém a relação familiar, principalmente a marital, interfere em suas atuações e decisões. Exemplo disso é apresentado no relato de Elza: "Fui convidada para ser candidata a vereadora e ele [o companheiro] não concordou com minha candidatura, eu ia ter bastante votos por ser bem conhecida na minha associação, mais acabei desistindo de me candidatar, já meus filhos me apoiam, alguns irmãos sim, outros não". No relato de Elza, é possível perceber que a posição do marido a impede de contribuir e participar ainda mais das decisões da comunidade e exercer o seu papel social com maior efetividade.

Sobre discriminação e preconceito em relação à participação das mulheres, algumas das entrevistadas relataram que, em Vilhena, é considerado menor do que em outros municípios do Estado. De acordo com a entrevistada Marielle: "Em outros municípios de Rondônia existe mais. 0 homem que está na presidência não deixa a mulher tomar posse, existindo mais preconceito do que aqui em Vilhena".

Outro fator importante diz respeito à comunicação entre os órgãos públicos e as associações. Para os representantes dos órgãos públicos, existem ações e políticas públicas que não se concretizam devido à falta da participação das mulheres. Sobre esse aspecto, é necessário não silenciar o fato de que existem entraves à participação feminina nas lideranças rurais. Para mobilizar a participação de mulheres no campo, é preciso compreender que tipo de comunicação é mais adequada, para que se possa garantir a divulgação e o amplo conhecimento do papel desses cargos. Para além disso, constatou-se, nas análises das entrevistas das mulheres, que para elas não há discriminação por parte dos representantes dos órgãos públicos, elas atribuem o processo discriminatório mais à família, especialmente aos seus maridos.

Para os dirigentes de órgãos públicos contatados durante o trabalho de campo, os homens estão se distanciando dos cargos de liderança das associações talvez por fatores como ausência de remuneração, exigência de tempo e dedicação. Para os homens, a atuação das mulheres como dirigentes é positiva. Os entrevistados acreditam ainda que os papéis da mulher como companheira, mãe e dirigente rural seja algo fácil de conciliar. 
Os homens priorizam trabalhos com uma carga produtiva maior e mais retorno financeiro. Ainda assim, a atuação das mulheres dirigentes de associações rurais é escassa e fica evidente a necessidade de se buscar a paridade de gênero nas decisões do campo. Devido às experiências adquiridas durante os anos de atuação em diversos cargos nas associações rurais, as mulheres possuem determinado poder em relação às tomadas de decisões.

Em relação ao retorno financeiro, fica evidente que as práticas dessas mulheres dirigentes estão relacionadas às reflexões de Melo e Sabbato (2009), quando afirmam que, no campo, a realidade feminina é reproduzida por meio de um trabalho sem remuneração, e, por isso, as mulheres têm dificuldades de ter a sua própria independência financeira; embora, assumam inúmeras atividades no ambiente rural. Apesar das dificuldades e das condições de como são estabelecidas as práticas das mulheres dirigentes das associações rurais, elas têm condições de exercer qualquer atividade conforme defendem Silva et al. (2016) e Galeazzi et al. (2003).

\section{CONCLUSÕES}

Este artigo investigou como as representações sociais sobre o gênero feminino dificultam a atuação das dirigentes de associações rurais. Por meio das narrativas das presidentas, presidentes e representantes de órgãos públicos, buscou-se compreender como são determinadas e impactadas as práticas das presidentas das associações rurais pela cultura machista e as representações normativas de gênero. Para além disso, buscou-se compreender também as representações e experiências das pessoas entrevistadas sobre as lideranças femininas. Assim, caracterizaram-se as condições de atuação dessas mulheres a partir das perspectivas dos Estudos de Gênero e da luta por igualdade de oportunidades.

Num primeiro momento, constatou-se que a discussão de gênero ainda é um assunto pouco discutido no ambiente rural. Por isso, o debate sobre essa temática e a divisão do trabalho é um assunto que deve ser fomentado, uma vez que pode levar as pessoas a reverem seus próprios conceitos. Paralelamente, foi possível constatar a necessidade de ampliar as discussões sobre gênero no ambiente rural, propor novos questionamentos em relação à atuação das mulheres nesse espaço e como há muito a ser discutido e conquistado nos estudos feministas e de gênero no campo rural. Nesse sentido, o artigo contribui para a 
literatura sobre relações de gênero, mulheres e trabalho ao proporcionar reflexões sobre a atuação das mulheres e as representações do papel delas como dirigentes de associações rurais.

É percebido que as associações rurais é um campo de organizações convivenciais que apresenta uma assimetria de gênero mais aguda do que em outros campos quando comparado ao exemplo de organização convivencial investigada no trabalho de Daher e Seifert Junior (2017). Também pode ser considerado que o papel de gerenciamento das associações rurais não é tão restrito conforme orienta Fraser (2009), porém essa afirmação se deve às características peculiares explicadas na discussão sobre a visão dos dirigentes das associações e dos órgãos públicos. Em suma, a atuação das mulheres nas associações rurais se mostrou mais complexa e machista do que em outras organizações convivenciais.

Verificou-se que elas possuem maior experiência nas associações e angariaram agência e autonomia em relação às questões de gênero, mas ainda há muito a ser conquistado. As análises demonstraram também que falta compreensão por parte dos homens dirigentes de associações e dos representantes dos órgãos públicos sobre a importância e as dificuldades de atuação que as mulheres presidentas de associações rurais experienciam. Mais do que isso, não há o entendimento da relevância da atuação feminina para o desenvolvimento do ambiente rural e das associações.

Por meio do trabalho de campo e da bibliografia consultada sobre organizações convivenciais, pode-se afirmar que as associações rurais se diferem de outros ambientes organizacionais, e o principal aspecto dessa diferença está relacionado à valoração do trabalho feminino no contexto rural, que é compreendido como "ajuda". Assim, é necessário tensionar as representações de gênero para que o trabalho das mulheres no campo seja visto como crucial para a (re)produção da vida no campo e para o seu devido protagonismo econômico. A economia feminista discutida por Faria (2009) se apresenta como uma abordagem a ser utilizada pelas associações rurais, pelas universidades e pelas mulheres do campo para modificar esse cenário.

Pode-se afirmar, a partir das análises dos dados, que as mulheres, que atuam nas associações rurais, enfrentam maiores dificuldades de tratamento no cargo de gestoras e 
diferenças de atuação do que as que atuam em ambientes organizacionais urbanos. Essas diferenças de atuação do machismo no ambiente rural vão além dos elementos geográficos contidos neste trabalho; além disso, devem ser consideradas ainda as dificuldades das discussões feministas chegarem ao ambiente rural. Assim, compreende-se que há muito a ser discutido e transformado para melhorar as relações de igualdade de gênero no ambiente rural e, consequentemente, na atuação das dirigentes de associações rurais.

A atuação das mulheres como presidentas de organizações rurais ainda ocorre de maneira conflituosa e desvalorizada, é importante que os homens que trabalham no ambiente rural compreendam a importância do trabalho dessas presidentas em termos econômicos, de crescimento e de manutenção dos negócios rurais. Os trabalhos dessas mulheres acrescentam muitas benesses, além da "ajuda", pois é considerado, tanto pelos dirigentes de associações quanto pelos dos órgãos públicos, que as mulheres atuam de modo eficaz na gestão das associações rurais.

Independente do gênero, há dificuldades na execução do cargo de presidente em associações rurais, principalmente, devido à distância dos centros urbanos, à falta de estrutura logística e de políticas públicas mais eficazes. No entanto, para as mulheres, as dificuldades são ainda maiores devido às representações sobre o gênero feminino no interior de uma cultura machista. Ao escolherem atuar nos cargos de gestão das associações, as mulheres mostram força, resiliência, determinação e o desejo de ajudar suas comunidades.

As experiências das presidentas nas associações rurais demonstram também a capacidade de atuação política das mulheres em espaços externos ao ambiente rural. De acordo com os pressupostos defendido por Serrano (2015) em relação ao fortalecimento da agroecologia, à aproximação com as discussões ambientais e à organização coletiva das mulheres, é possível inferir que, por meio da atuação na direção das associações rurais, essas mulheres adquirem experiências, competências e habilidades para ocupar outros espaços de atuação, por exemplo, cargos eletivos políticos que possibilitariam a inserção feminina nas esferas governamentais de decisão do Estado de Rondônia e no Congresso Nacional.

A aplicação da análise de conteúdo permitiu às pessoas pesquisadoras compreender como se estabelecem as relações perante a atuação das mulheres dirigentes de associações 
rurais no campo pesquisado. Por meio dessa metodologia, foi possível analisar de maneira coerente e integrativa as considerações dos presidentes de associações rurais e dirigentes de órgãos públicos relacionados ao ambiente rural.

Um fator limitador a este trabalho foi a dificuldade de identificar as associações e seus presidentes e presidentas e, posteriormente, conseguir contato com as pessoas entrevistadas. Assim, as adversidades de ingresso ao ambiente rural também possibilitam constatar as dificuldades de acesso a informações, por exemplo, os relacionados às discussões de gênero e feminismos.

Sugere-se que novos estudos, com uso de outros métodos e de outras técnicas de pesquisas, sejam realizados no intuito de aprofundar ainda mais as análises sobre as diferenças e igualdade de gênero e a participação das mulheres em organizações do ambiente rural. Essas novas pesquisas poderão ser conduzidas com os presidentes de associações rurais, com representantes de órgãos públicos para que se possa compreender o papel desses atores sociais como facilitadores ou não da participação feminina no espaço rural e/ou por um estudo comparativo entre as relações de mulheres dirigentes de associações rurais e de mulheres dirigentes de outros complexos organizacionais. É necessário abrir novos campos de debate sobre a temática de gênero e de suas relações de trabalho no campo para que se possa compreender que o lugar da mulher é onde ela quiser - e deve ser respeitado de maneira igualitária, sem que haja qualquer discriminação negativa sobre o seu gênero, sendo em casa, no trabalho ou nas lideranças de associações rurais. Por fim, os resultados das atividades das mulheres seriam mais eficientes se houvesse políticas mais efetivas para diminuir os obstáculos colocados por uma cultura machista que invisibiliza o trabalho feminino.

\section{REFERÊNCIAS}

ALVES, José Eustáquio Diniz. Desafios da equidade de gênero no século XXI. Estudos feministas, UFSC, $\quad \mathrm{n}$ o $\quad 24(2), \quad 2016 . \quad$ Disponível em: https://periodicos.ufsc.br/index.php/ref/article/view/44610/31761. Acesso em: 19 abr. 2017. 
AMES, Marise. Waschburguer; BUTTERNBENDER, Pedro Luís. A participação da mulher no cooperativismo rural na ótica de lideranças participantes do sistema: uma abordagem na região fronteira noroeste. UNIJUÍ, IJUÍ-RS, 2012. Disponível em: https://bibliodigital.unijui.edu.br:8443/xmlui/handle/123456789/547. Acesso em: 19 abr. 2017.

BARBOSA. Ana Luiza Neves de Holanda. Participação feminina no mercado de trabalho brasileiro. IPEA, Mercado de Trabalho, 57, 2014, p. 31-41. Disponível em: http://repositorio.ipea.gov.br/bitstream/11058/3736/1/bmt57 nt02 participa\%C3\%A7\%C 3\%A3o.pdf . Acesso em: 21 mar. 2018.

BENOIT, Lelita Oliveira. Feminismo, gênero e revolução. Crítica marxista, Unicamp, n. 11, 2000. Disponível em: https://www.ifch.unicamp.br/criticamarxista/arquivos biblioteca/05lelita.pdf. Acesso em: 19 abr. 2017.

BRUMER, A. Gênero e agricultura: a situação da mulher na agricultura do Rio Grande do Sul. Estudos Feministas, UFSC, no 1, 2004. Disponível em: http://www.scielo.br/pdf/ref/v12n1/21699. Acesso em: 03 nov. 2018.

BUTLER, Judith. Problemas de gênero: feminismo e subversão da identidade. $3^{a}$ edição. Rio de Janeiro: Civilização Brasileira, 2010.

CAMPOS, Christiane Senhorinha Soares. A face feminina da pobreza em meio à riqueza do agronegócio. Cruz Alta: Outras Expressões, 2011.

CARVALHO, Ludmilla Luciano de. Agricultoras familiares: resistência e construção de alternativas ao agronegócio. Coletânea sobre estudos rurais e gênero, Prêmio Margarida Alves 4. edição, Brasília: Ministério do Desenvolvimento Agrário, 2015

CASTAÑON, Gustavo Arja. Construtivismo social: uma crítica epistemológica. Temas em Psicologia da SBP, $\mathrm{n}^{\mathrm{o}}$ 1, 2004. Disponível em: http://pepsic.bvsalud.org/pdf/tp/v12n1/v12n1a08.pdf. Acesso em: 04 ago. 2017. 
CIELO, Ivanete Daga; WENNINGKAMP, Keila Raquel; SCHMIDT, Carla Maria. A participação feminina no agronegócio: o caso da Coopavel - Cooperativa Agroindustrial de Cascavel. Revista Capital Científico-Eletrônica, v. 12, no 1, 2014, p. 59-77.

CONCEIÇÃO, Eliane Barbosa da. Mulher negra em terra de homem branco: mecanismos de reprodução de desigualdades. In: CARRIERI, Alexandre de Pádua; TEIXEIRA, Juliana Cristiana; NASCIMENTO, Marco Cesar Ribeiro (Orgs.). Gênero e Trabalho: perspectivas, possibilidade e desafios no campo dos estudos organizacionais. Salvador: Edufba, 2016, p. 277-320.

DAHER, Stephanie; SEIFERT JÚNIOR, Rene E. Gênero em organizações convivenciais: possibilidades de um espaço de redistribuição, reconhecimento e representação. Anais do IV Colóquio Internacional de Epistemologia e Sociologia da Ciência da Administração. Florianópolis, de 26 a 28 de abril de 2017. Disponível em: www.scielo.br/pdf/cebape/v14n1/1679-3951-cebape-14-01-00001.pdf. Acesso em: 04 ago. 2017.

DELLAGNELO, Eloise Helena Livramento; SILVA, Rosimeri Carvalho. Análise de conteúdo e sua aplicação em pesquisa na administração. In: VIEIRA, Marcelo Milano Falcão; ZOUAIN, Deborah Moraes (Orgs.). Pesquisa qualitativa em administração: teoria e prática. Rio de Janeiro: FGV, 2005. p. 97-118.

Empresa Brasileira de Pesquisa Agropecuária - Embrapa. Concentração Geográfica da Agricultura Familiar No Brasil. 2013. Disponível em: https://www.infoteca.cnptia.embrapa.br/bitstream/doc/965105/1/doc155.pdf. Acesso em: 14 maio 2017.

FARAH, Marta Ferreira Santos. Gênero e políticas públicas. Estudos Feministas, UFSC, nํㅜ 1, 2004. Disponível em: http://www.scielo.br/pdf/ref/v12n1/21692. Acesso em 04 nov. 2018.

FARIA, Nalu. Economia feminista e agenda de luta das mulheres no meio rural. In: Sabbato, Alberto; MELO, Hildete Pereira de; LOMBARDI, Maria Rosa; FARIA, Nalu; BUTTO, Andrea (Orgs.). Estatísticas rurais e a economia feminista: um olhar sobre o trabalho das mulheres. Brasília: MDA, 2009. p. 11-28. 
FLICK, Uwe. Introdução à pesquisa qualitativa. 3a ed. Porto Alegre: Artmed, 2009.

FRASER, Nancy. Reenquadrando a justiça em um mundo globalizado. Lua Nova, Centro de Estudos de Cultura Contemporânea - CEDEC, no 77, 2009. Disponível em: http://www.scielo.br/pdf/ln/n77/a01n77.pdf. Acesso em: 10 abr. 2018.

GALEAZZI, Irene Maria Sassi; GARCIA, Lúcia; DRIEMEIER, Maria Munhoz; TONI, Miriam De; KRELING, Norma Hermínia; FOLLADOR,Patrícia. Mulheres trabalhadoras: 10 anos de mudanças no mercado de trabalho atenuam desigualdades. Mulher e Trabalho, Porto Alegre, v. 3 2003. Disponível em: https://revistas.fee.tche.br/index.php/mulheretrabalho/article/view/2690/3012. Acesso em: 10 Dez. 2017.

GODOY, Arilda Schmidt. Estudo de caso qualitativo. In: GODOI,Christiane Kleinübing; BANDEIRA-DE-MELLO, Rodrigo; SILVA, Anielson Barbosa (Orgs.). Pesquisa qualitativa em estudos organizacionais: paradigmas, estratégias e métodos. $2^{\underline{a}}$ ed. São Paulo: Saraiva, 2010, p. 115-146.

GOMES, Almiralva Ferraz. Ação empreendedora e relações de gênero: um estudo multicasos na cidade de Vitória da Conquista. Ufla (Tese doutorado), Lavras-MG, 2010. Disponível em: http://repositorio.ufla.br/bitstream/1/2754/1/TESE A\%C3\%A7\%C3\%A30\%20empreende dora $\% 20 \mathrm{e} \% 20$ rela\%C3\%A7\%C3\%B5es\%20de\%20g\%C3\%AAnero.pdf. Acesso em: 08 ago. 2017.

HARAWAY, Donna. Manifesto Ciborgue. In. HARAWAY, Donna; KUNZRU, Hari; SILVA, Tadeu Silva (Orgs.). Antropologia do Ciborgue: as vertigens do pós-humano, organização e tradução Tomaz Tadeu Silva, 2ª ed. Belo Horizonte: Autêntica, 2009.

HOSKING, Dian Marie. Telling Tales of Relations: Appreciating Relational Constructionism. Organization Studies, v. 32, n.1, 2011, p. 47-65. Disponível em: https://www.researchgate.net/publication/228714653 Telling Tales of Relations Appreciat ing Relational Constructionism. Acesso em: 08 ago. 2018. 
INSTITUTO BRASILEIRO DE GEOGRAFIA E ESTÁTICAS - Ibge. Censo Estados. 2010.

Disponível

em:

http://www.ibge.gov.br/estadosat/temas.php?sigla=ro\&tema=censodemog2010 amostra.

Acesso em: 21 abr. 2017.

Instituto de Pesquisa Econômica Aplicada - Ipea. Relatório de Pesquisa Perfil Socioeconômico e Condições de Vida das Mulheres Trabalhadoras do Campo e da Floresta. 2012.

Disponível

em:

http://www.ipea.gov.br/agencia/images/stories/PDFs/relatoriopesquisa/121220 relatorio perfil socioeconomico.pdf. Acesso em: 10 Dez. 2017.

JARDIM, Gabriel de Sena; CAVAS, Claudio São Thiago. Pós-colonialismo e feminismo decolonial: caminhos para uma compreensão anti-essencialista do mundo. Ponto e Vírgula PUC-SP, $\quad \mathrm{n}^{0}$ 22, 2017.2 Disponível em: https://revistas.pucsp.br/index.php/pontoevirgula/article/view/33335. Acesso em: 08 jan. 2020.

KINOSHITA FailonMitinori; BATILANI, Italo. A desigualdade de gênero no trabalho do campo. Anais do I Seminário de Educação e Diversidade do Campo. Paranavaí-PR, 27 e 28 set. 2016. Disponível em http://www.fafipa.br/educampo/resexp/A\%20DESIGUALDADE\%20DE\%20GEN\%C3\%8ARO \%20NO\%20TRABALHO\%20DO\%20CAMPO.pdf. Acesso em 08 ago. 2017.

MELO, Hildete Pereira de; Sabbato, Alberto. Gênero e trabalho rural 1993/ 2006. In: Sabbato, Alberto; MELO, Hildete Pereira de; LOMBARDI, Maria Rosa; FARIA, Nalu; BUTTO, Andrea (Orgs.). Estatísticas rurais e a economia feminista: um olhar sobre o trabalho das mulheres. Brasília: MDA, 2009. p. 31-121.

MORGADO, Ana Paula Dente Vitelli. A mulher invisível: sentidos atribuídos à mulher e ao trabalho na gerência intermediária. Escola de Administração de Empresas de São Paulo da Fundação Getulio Vargas (Tese doutorado). São Paulo, 2012. 
MORGADO, Ana Paula Dente Vitelli; TONELLI, Maria José. Mulheres executivas: o velho e o novo nos estudos sobre gênero e trabalho. In: CARRIERI, Alexandre de Pádua; TEIXEIRA, Juliana Cristina; NASCIMENTO, Marco Cesar Ribeiro (Orgs.). Gênero e Trabalho: perspectivas, possibilidade e desafios no campo dos estudos organizacionais. Salvador: Edufba, 2016, p. 159-188.

NARVAZ, Martha Giudice; KOLLER, Sílvia Helena. Metodologias feministas e estudos de gênero: articulando pesquisa, clínica e política. Psicologia em Estudo, Maringá, nº 3, 2006. Disponível em: http://www.scielo.br/pdf/pe/v11n3/v11n3a20.pdf. Acesso em: 10 Ago. 2019.

OLIVEIRA, Mirian; BITENCOURT, Claudia Cristina; MATTE, Ana Clarissa Zanardo dos Santos; KUNZEL, Eduardo Teixeira. Análise de Conteúdo Temática: há uma diferença na utilização e nas vantagens oferecidas pelos softwares MAXQDA® e NVivo@?.Revista de Administração da UFSM, Santa Maria, no 1, 2016. Disponível em: https://www.redalyc.org/pdf/2734/273445396006.pdf. Acesso em: 10 Jan. 2020.

QUARESMA, Amanda Paiva. Mulheres e quintais agroflorestais: a "ajuda invisível" aos olhos que garante a reprodução da agricultura familiar camponesa amazônica. Coletânea sobre estudos rurais e gênero, Prêmio Margarida Alves, $4^{\underline{a}}$ ed. Brasília: Ministério do Desenvolvimento Agrário, 2015.

RODRIGUES, Marcio Silva. Epistemologia e Administração: (um esboço de) Reflexões e possibilidades. Perspectivas contemporâneas, Centro Universitário Integrado, no 1, 2013. Disponível

em:

http://revista2.grupointegrado.br/revista/index.php/perspectivascontemporaneas/article/v iew/1259/503. Acesso em: 10 mar. 2018.

SCOTT, Joan Wallach. Gênero: uma categoria útil de análise histórica. Educação e realidade, v. 20, no 2, Porto Alegre, jul./dez. 1995, p. 71-99.

SERRANO, Julia Scaglioni. Mulheres da Borborema: Construindo a igualdade de gênero e a agroecologia. Coletânea sobre estudos rurais e gênero, Prêmio Margarida Alves, 4⿳亠丷a ed. Brasília: Ministério do Desenvolvimento Agrário, 2015. 
SERVIÇO NACIONAL DE APRENDIZAGEM RURAL (SENAR). Associações rurais: práticas associativas, características e formalização. Brasília: SENAR, 2011.

SILIPRANDI, Emma. Rompendo a inércia institucional: as mulheres rurais e a política nacional de agroecologia e produção orgânica. In: SAMBUICHI, Regina Helena Rosa; MOURA, Iracema Ferreira de; MATTOS, Luciano Mansor; ÁVILA, Mário Lúcio; SPÍNOLA, Paulo Asafe Campos; SILVA, Ana Paula Moreira da. (Orgs.). A política nacional de agroecologia e produção orgânica no Brasil: uma trajetória de luta pelo desenvolvimento rural sustentável. Brasília, Ipea, 2017, p. 277-294. Disponível em: http://www.ipea.gov.br/agencia/images/stories/PDFs/livros/livros/144174 politica nacion al agroecologia cap09.pdf. Acesso em: 15 mar. 2018.

SILVA, Andressa Hennig; FOSSÁ, Maria Ivete Trevisan. Análise de conteúdo: exemplo de aplicação da técnica para análise de dados qualitativos. Qualit@s Revista Eletrônica, v.17, no $1, \quad$ p. $1-14, \quad 2015 . \quad$ Disponível em: http://revista.uepb.edu.br/index.php/qualitas/article/view/2113/1403. Acesso em: 01 jul. 2020.

SILVA, Paulo Marlon Medeiros; ROCHA NETO, Manoel Pereira; BRITO, Lydia Maria Pinto; BARRETO, Laís Karla da Silva; GURGEL, Fernanda Fernandes. Equidade de Gênero nas Organizações: O Trabalho e os Desafios da Mulher na Construção Civil. Revista Organizações em Contexto, Instituto Metodista de Ensino Superior, no 24, 2016.. Disponível em: http://www.spell.org.br/documentos/ver/43243/equidade-de-genero-nas-organizacoes--otrabalho-e-os-desafios-da-mulher-na-construcao-civil-. Acesso em 15 abr. 2017.

SOUZA, Mariana Mayumi Pereira de; CARRIERI, Alexandre de Pádua. Identidades, práticas discursivas e os estudos organizacionais:uma proposta teórico-metodológica. Cad. EBAPE.BR, FGV, $\mathrm{n}^{\mathrm{o}}$ 1, $2012 . \quad$ Disponível em: http://bibliotecadigital.fgv.br/ojs/index.php/cadernosebape/article/view/5245. Acesso em: 17 abr. 2018. 